\title{
Joanna KUĆ
}

Uniwersytet Przyrodniczo-Humanistyczny w Siedlcach joanna.kuc@post.pl

\section{AKTY USZANOWANIA I POZWOLENIA NA ZAWARCIE MAEŻEŃSTWA JAKO UMOWY INTERTEKSTUALNE}

Pojęcie intertekstualności doczekało się wielu interpretacji, szczególnie na gruncie literaturoznawstwa, z którego się wywodzi ${ }^{1}$. Jest to zarówno strategia recepcji dzieł wykorzystywana w badaniach tekstologicznych, jedno z podstawowych "narzędzi" tych badań, jak i paradygmat wielu analiz i interpretacji utworów nie tylko literackich, chętnie zapożyczany przez wszystkie dyscypliny zajmujące się szeroko pojętą komunikacją. Coraz częściej badacze przyglądają się temu inspirującemu zjawisku przez pryzmat całej komunikacji międzyludzkiej, co też nie pozostało bez wpływu na metodologię badań.

Punktem wyjścia dla teorii intertekstualności jest teza, że każdy tekst jest tworzony i odbierany nie tylko w odniesieniu do kodowych potencji języka, lecz pozostaje także $\mathrm{w}$ odniesieniu do tekstów uprzednich i następczych oraz zawiera sygnały tych odniesień (Gajda 2010: 13). W opracowaniach literaturoznawczych i językoznawczych intertekstualność traktuje się jako sferę powiązań i odniesień międzytekstowych (obszerną bibliografię dotyczącą intertekstualności znajdziemy w pracach Głowińskiego 1986, Nycza 1993, Balbusa 1993). Takie podejście badawcze wynika z założenia, że tekst tworzy sens "poprzez współistniejące z nim konteksty" (Cieślikowska 1995: 102). Tymczasem zjawiska związane z intertekstualnością jako kategorią ontyczno-epistemiczną powinny być rozpatrywane z różnych punktów widzenia: empirii komunikacyjnej, powiązań

1 Pojęcie intertekstualności, które wyrosło z bachtinowskiej koncepcji dialogiczności, zostało wprowadzone do badań literackich przez Julię Kristevą w 1967 r. 
międzytekstowych, dyskursywnych i generycznych odniesień, różnych poziomów organizacji wzorca (strukturalnego, pragmatycznego, poznawczego, stylistycznego), co też proponuje M. Wojtak (2010: 232-233). Zdaniem badaczki, są to odniesienia wielowymiarowe, polimorficzne, które pokazują dynamikę zjawisk komunikacyjnych, decydujących o kształcie tekstu, a ich rozpiętość jest ogromna. Relacje, o których mowa, można obserwować przez pryzmat konkretnych tekstów jako wszelkie odniesienia językowe, stylowe, gatunkowe zaświadczone w strukturze tekstu i na wszystkich poziomach komunikacji ${ }^{2}$. W wyniku tych procesów dokonuje się "semantyczna aktywizacja co najmniej dwóch tekstów”, jak eksplicytnie określa granice intertekstualności M. Głowiński (Głowiński 2000: 14).

W niniejszym opracowaniu przyjrzę się zjawisku intertekstualności w XIX-wiecznych notariatach sporządzonych w kancelarii Józefa Kalasantego Szaniawskiego w Łukowie. $Z$ repertorium akt wynika, że akty uszanowania i pozwolenia na zawarcie małżeństwa należały do często praktykowanych czynności w owym czasie, w latach 1810-1811 w rzeczonej kancelarii zarejestrowano łącznie 63 jednostki (33 akty uszanowania i 30 pozwoleń). Liczba omawianych dokumentów notarialnych jest zbliżona ze względu na wzajemność i dwukierunkowość wskazanych czynności prawnych. W obu typach umów odnajdujemy wiele sygnałów obustronnych relacji tekstowych, w postaci nawiązań strukturalnych oraz interakcji natury pragmatycznej, komunikacyjnej. Artykuł ma na celu ich wskazanie, scharakteryzowanie oraz przedstawienie uwarunkowań i funkcji odwołań intertekstualnych.

Akty uszanowania są to krótkie, jednostronicowe umowy zawarte między rodzicami lub - w wypadku ich braku - najbliższymi krewnymi i dziećmi, zamierzającymi zawrzeć związek małżeński. Mają formę prośby o rodzicielskie błogosławieństwo, są jednocześnie urzędowymi dokumentami umocowanymi prawnie, co rejent zaznacza każdorazowo w narracji, por. S-13: (...) dopetniając Prawo Kodexu Wielkiego Napoleona pod artykułem Sto Pięćdziesiąt Jeden, wyrażone czyniq (...). W podpisaniu aktów uczestniczyły rodziny obojga narzeczonych, których notariusz wska-

2 Takie rozumienie intertekstualności zostało zaproponowane między innymi przez R. Nycza (1990: 97).

3 Poszczególne akty zostały opatrzone inicjałem nazwiska notariusza i ponumerowane zgodnie $\mathrm{z}$ zapisem $\mathrm{w}$ repertorium akt. 
zuje $\mathrm{w}$ formule wstępnej (enumeracji), jednakże nie nazywa ich zeznającymi/zeznawajacymi, tę rolę wyznacza kawalerom i pannom. Do aktów uszanowania stawały osoby stanu wolnego, znane z imienia, nazwiska, pochodzenia, stanu cywilnego, wieku i koligacji rodzinnych, czego wyraźnie sygnały znajdują się już we wstępie dokumentów, por. S-29: Stawiąc się osobiście Starozakonny Abraham Leyzor Gecowicz, tu w Łukowie pod Numerem Sto Osiemdziesiat przy Matce swoiey Gitli Gecowej mieszkający, Urzędowi swemu Znany, petnoletni, na Ciele i Umysle zdrowy, do działania Urzędowego $z$ dolny (...).

Prośba o błogosławieństwo sformułowana jest zawsze $\mathrm{w}$ ten sam sposób w postaci struktur językowych charakterystycznych dla wzorca ustalonego przepisami legislacyjnymi, co oznacza, że wszystkie akty tego typu mają sformalizowaną treść, por. S-12: J்̇ Ciż wyżey wyrażeni Zeznawaiacy Kawaler y Panna, chcac z Sobq Wniść w Zwiazek Małżeński, stosownie do Prawa Kodexu Wielkiego Napoleona, pod artykułem Sto Pięćdziesiąt Jeden, y Sto Pięćdziesiąt Cztery, wyrażonego, akt uszanowania, to iest Urodzony Franciszek Krasuski, Urodzoney Maryannie z Jastrzębskich Krasuskiey Matce swoiey, Urodzona zaś Agnieszka Sulejowna, Urodzonym Onufremu y Franciszce z Zalewskich Małżonkom Sulejow, Oycu i Matce swoim, czynia, y dopraszając sie iak naypokorniey, aby Jm w sluby matżeńskie wniść ze sobq żadaiacym, Rady y Błogosławieństwa Swego, Ciż wyżey wyrażeni Rodzice udzielili, y pobrać się zez sobq dozwolili (...). Z kolei formuła finalna zawiera precyzyjne określenie przedmiotu umowy, por. S-12: O co niniejszym aktem czynionego uszanowania prosząc, tenże maiąc Sobie ninieysze zeznanie głosno y wyraźnie przeczytane, wtasnoręcznie wraz ze Swiadkami Ciż zenawaiacy podpisali iak naztępuie (...).

Pozwolenia na zawarcie małżeństwa są reakcją rodziców na akty uszanowania złożone im przez przyszłych nowożeńców, stąd numeracja poszczególnych umów następuje wyraźnie po sobie, por. S-1 to ąkt uszanowania, S-2 to pozwolenie na zawarcie matżeństwa itd. Pozwolenia na zawarcie małżeństwa, jako odpowiedzi na akty uszanowania, są aktami asercji (oświadczeń woli), podobne formalnie i zależne od tych pierwszych, bowiem treść obu deklaracji jest bezpośrednio ze sobą powiązana sytuacyjnie, przedmiotowo, osobowo i czasowo. Narracja właściwa aktów pozwolenia, w formie ciągłej, zaczyna się od słów, por.: İ் oni zapatrzywszy się na Akt Uszanowania przez Urodzonych Piotra Paszkowskiego i Antoninę Rolankę do Zwiazku Małżenskiego zabieraiacych się sobie Zeznawaiacym Uczyniony i w Aktach Notaryusza pod dniem dzisiejszym zapisany, na Zwiazek 
Małżenski między temiż nastapić miany, Zyczac Jm Błogosławienstwa Boskiego, i najlepszego między soba pożycia Zezwalaia (...) S-2. Wyraźnie więc S-1 i S-2 oraz kolejne parzyste umowy są powiązane poprzez przywołanie w narracji kontekstu ich zawarcia. Oba typy dokumentów mają analogiczną strukturę i kompozycję, tzn. zawierają prezentację stron, świadków i sugestię, że jest to zeznanie o mocy urzędowej: Jawnie, dobrowolnie y rozmyślnie zeznali y ninieyszym zeznaja / oczywiście i dobrowolnie zeznali S-12, po czym w obu umowach następuje narracja właściwa, opisująca przedmiot czynności prawnej.

Akty uszanowania są bardzo silnie umocowane prawnie, bowiem zawierają presupozycyjne odniesienia do Kodeksu Wielkiego Napoleona i stosownych jego artykułów, por. S-18: stosownie do Prawa Kodexu Wielkiego Napoleona pod Artykułem Sto Pięćdziesiąt Jeden i Sto Pięćdziesiąt Cztery wyrażonego, Akt Uszanowania (...). Pozwolenia na zawarcie małżeństwa takich odniesień prawnych nie zawierają, opierają się na aktach uszanowania, a ich moc illokucyjna nie jest przez to słabsza. Są referencyjne prawnie, bo wynikają z okoliczności wcześniej realizowanej czynności notarialnej. Jest to istotna cecha, wskazująca na relacje wynikowe między tekstami, które można powiązać z intertekstualnością.

Wprawdzie oba typy aktów, tj. uszanowania i pozwolenia, mogą być dzisiaj czytane w dowolnej kolejności, jednak razem tworzą semantyczną całość, w której pierwszeństwo ról prawnych jest wyraźnie założone. Wobec takich przesłanek, akt uszanowania jawi się jako tekst precedentny - prośba, która wywołuje odpowiedź w postaci pozwolenia na zawarcie małżeństwa. Pierwszeństwo relacji zakłada sytuacja komunikacyjna, zgodnie z którą rejent przedstawia w enumeracji strony i świadków czynności prawnych w odpowiedniej kolejności i perspektywie. Eksponują ją zwłaszcza parametry kontekstowe: charakterystyka uczestników komunikacji raz z perspektywy syna i przyszłej synowej, innym razem - rodziców, eksplicytne odwołania do wszystkich uczestników w obu typach aktów oraz analogie w ich przedstawianiu, por. S-12: Przedemna niżey podpisanym Urzędnikiem Pisarzem Publicznym Aktowym Powiatu Łukowskiego do tego aktu wezwanym Stawiąc się osobiście Urodzeni, Franciszek Krasuski, niegdy Urodzonego Dominika Krasuskiego Syn z Żyiaca Maryanna z Jastrzębskich $w$ Małżenstwie spłodzony, w Wsi Zalesiu w Powiecie Eukowskim, Departamencie Siedleckim, na Dziedzictwie swoim mieszkajacy, Urzędowi swemu znany, Pełnoletni, na Ciele i Umysle zdrowy, do działania urzędowego zdolny, y Agnieszka Sulejowna, Urodzonych Onufrego, y Franciszki z Zaleskich Małzonków Sulejow, 
Corka, w wyżey wyrażoney wsi Zalesiu przy Rodzicach mieszkająca, Urzędowi swemu znana, petnoletnia, na Ciele i Umysle zdrowa, do działania Urzędowego zdolna, w Przytomności Swiadkow, to iest (...).

Zestawmy, dla przykładu, S-13, będący pozwoleniem na zawarcie małżeństwa, w którym mamy wyraźnie odwrócenie ról prawnych: Przedemna niżey podpisanym Urzędnikiem Pisarzem Publicznym Aktowym Powiatu Łukowskiego do tego aktu wezwanym Stawiąc się osobiście Urodzeni, Maryanna z Jastrzębskich, niegdy Urodzonego Dominika Krasuskiego Matżonka, pozostała Wdowa, we Wsi Zalesiu, w poszeszyi swoiey Dożywotniey Mieszkaiaca, Urzędowi swemu znana, Petnoletnia, na Ciele i Umysle zdrowa, do działania urzędowego zdolna, y Onufry, tudzież Franciszka z Zaleskich Małżonkowie Suleja, także w Zalesiu w Powiecie Łukowskim, Departamencie Siedleckim, na Dziedzictwie swoim mieszkający, Urzędowi swemu znani, Pełnoletni, na Ciele $i$ Umysle zdrowi, do działania urzędowego zdolni, w Przytomności Swiadkow to iest (...).

Także elementy komparycji wykazują podobne referencje $w$ obu typach aktów, są to treści obligatoryjne, w których można dostrzec hipertekstualne ${ }^{4}$ nawiązania poprzez łączliwość wtórnego tekstu (pozwolenia) z jego wcześniejszym wzorem (aktem uszanowania). Ślady powiązań przejawiają się w zmiennej perspektywie komunikacji, charakterze i kierunku relacji. Zawarte w porządku i organizacji informacji w tekście wartościowanie uczucia syna do rodziców i rodziców do syna ujawnia się $\mathrm{w}$ postaci pytania i odpowiedzi - tekstach identycznych kompozycyjnie i strukturalnie. Podobieństwo to dodatkowo eksponuje język prezentowanych aktów. Już na poziomie pragmatycznym dyskursu ujawnia się intertekstualny potencjał obu typów umów, w relacjach prośba-odpowiedź na prośbę, jako szeroko pojętej komunikacji. Dwustronna komunikacja rodzice-dzieci i dzieci-rodzice poprzez zadanie pytania i uzyskanie na nie odpowiedzi wpisuje się łańcuch konotacji kulturowych i zachowań kulturowo-komunikacyjnych, są to odwołania o charakterze dyskur-

\footnotetext{
4 Zgodnie z teorią Genette'a, typologia relacji transtekstualnych obejmuje pięć typów relacji: 1) intertekstualność (tekst w tekście, cytat, aluzja, plagiat), 2) paratekstualność (komentarze do utworu - przedmowa, posłowie, tytuł, epigraf), 3) matatekstualność (komentarz w tekście dotyczący innego tekstu), 4) hipertekstualność (łączenie hipertekstu z wcześniejszym hipotekstem i 5) architekstualność (odsyłanie do cech gatunkowych tekstu), por. G. Genette, Palimpsests. La literature au second degre, Paris 1982. Polemikę z tą koncepcja podjął M. Głowiński, podając w wątpliwość rozróżnienie między hipertekstualnością i intertekstualnością, przy akceptacji pojęć hipotekst i hipertekst, por. M. Głowiński, O intertekstualności, [w:] Poetyka i okolice, Warszawa 1992, s. 94-95.
} 
sywnym. Przestrzeń dyskursu jest zaimplikowana, zaś rola podmiotów zaangażowanych w komunikację zmienna. Są to modyfikacje, które dodatkowo eksponują zmieniające się role prawne, a te $\mathrm{z}$ kolei wpływają na zmianę sytuacji komunikacyjnej widzianej z różnych punktów widzenia. Uwarunkowania te mają charakter dynamiczny, podobnie jak sama zmiana perspektywy komunikacyjnej. Analizowane zmienne nie prowadzą jednak do rekonfiguracji strukturalnej i kompozycyjnej tekstów. Są one trwałe, podobnie jak intencje komunikatów.

Wskazane interferencje zakładają za to pewne transformacje samego tekstu w postaci uporządkowania informacji o danych osobowych czy zmianie perspektywy nadawca-odbiorca. W dalszej kolejności w tekście wtórnym pojawiają się metatekstualne nawiązania w postaci komentarza dotyczącego tekstu pierwotnego, czy szerzej - fragmentu tekstu zaim-

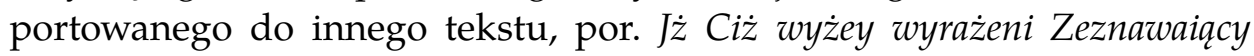
zapatrzywszy się na akt uszanowania, przez Urodzonych Franciszka Krasuskiego y Agnieszkę Sulejownę do związku małżeńskiego zabieraiacych się (...). Z punktu widzenia intertektualności narracja właściwa pozwoleń zawiera istotny element - jest to bezpośrednie odwołanie do tekstu pierwotnego, tj. aktu uszanowania.

Równie wysoki jest stopień tematyzacji jednego teksu w drugim, bowiem oba akty uszanowania i pozwolenia skupiają swą uwagę na błogosławieństwie, będącym istotą opisywanych czynności prawnych. Odniesienia tematyczne są tu istotne i ścisłe, i sprawiają, że komunikacja w obu typach aktów: uszanowania i pozwolenia wiąże się z formami deklaratywnymi. Egzemplifikują je stosowne fragmenty pozwoleń, por. S-30: na tenże Związek Małżenski nastapić miany, Błogosławiąc tymże przyszłym małżonkom Zezwala (...); S-47: na Zwiazzek Matżenski (...) nastapić miany, udzielaiąc im Błogosławieństwa swoiego pozwalaia Moca niniejszego Zeznania swoiego (...).

Zakres i charakter odniesień między komunikatami aktów uszanowania i pozwoleń zależy od notariusza, który jest medium narzucającym konwencję. Zatem relacje miedzy obu typami aktów notarialnych, oparte niejednokrotnie na repetycji składników, wiążą się z determinacją komunikacji urzędowej, która sama w sobie nosi znamiona intertekstualności. Jest to działalność podporządkowana celom dyskursu instytucjonalnego, który w przekazach notarialnych respektuje społeczne zachowania komunikacyjne i różne role podmiotów postrzegane z rozmaitych perspektyw. Intencją takiego przekazu jest zmiana rzeczywistości pozajęzykowej. 
Przywołując opinię A. Dunin-Dudkowskiej, zgodnie z którą „intertekstualność aktów notarialnych jawi się jako warunek sine qua non dla ważności i skuteczności aktu notarialnego", nie sposób się z nią nie zgodzić. Dyskursywne i generyczne odniesienia aktów uszanowania i pozwoleń na zawarcie małżeństwa, jak i poziom organizacji wzorca strukturalnego, pragmatycznego, poznawczego i stylistycznego sprawia, że opisywane typy XIX-wiecznych aktów są tekstami silnie powiązanymi intertekstualnie. Ich referencyjność ujawnia się w różnych obszarach komunikacji i na wielu jej poziomach, przy równie mocno zaznaczonej modalności relacji (Markiewicz 1989: 222-225). Jak sugerują badacze - to wieloaspektowe spełnienie wymogu intertekstualności było istotne dla komunikacji zinstytucjonalizowanej odbywającej się za pośrednictwem notariusza. Decydowało o asocjatywnym powiązaniu sensów i dyskursów (Steyer 1997).

\section{CYTOWANA LITERATURA}

Balbus S., Między stylami, Kraków 1993.

Cieślikowska T., W kręgu genologii, intertekstualności, teorii sugestii, Warszawa-Łódź 1995.

Dunin-Dudkowska A., Intertekstualność w akcie notarialnym, [w:] Intertekstualność we wspótczesnej komunikacji językowej, red. J. Mazur, A. Małyska, K. Sobstyl, Lublin 2010, s. 261-274.

Gajda S., Intertekstualność a wspótczesna lingwistyka, [w:] Intertekstualność we wspótczesnej komunikacji językowej, red. J. Mazur, A. Małyska, K. Sobstyl, Lublin 2010, s. 13-23.

Genette G., Palimpsests. La literature au second degre, Paris 1982.

Głowiński M., O intertekstualności, „Pamiętnik Literacki”, z. 4 (przedruk m.in. [w:] tenże, Prace wybrane, t. V, Kraków 2000, s. 5-33).

Głowiński M., O intertekstualności, [w:] Poetyka i okolice, Warszawa 1992, s. 94-95.

Markiewicz N., Odmiany intertekstualności, [w:] Literaturoznawstwo i jego sąsiedztwa, 1989 , s. 198-228.

Nycz R., Tekstowy świat, Warszawa 1993.

Steyer K., Reformulierungen. Sprachliche Relationen zwischen Äußerungen und Texten im öffentlichen Diskurs, Tübingen 1997.

Wojtak M., Wymiary i przestrzenie intertekstualności w tekstach użytkowych, [w:] Intertekstualność we wspótczesnej komunikacji jezzykowej, red. J. Mazur, A. Małyska, K. Sobstyl, Lublin 2010, s. 226-239. 


\section{ACTS OF RESPECT AND PERMISSION TO MARRY AS AN INTERTEXTUAL NOTARIAL CONTRACTS}

\section{Summary}

In this article I will look at the phenomenon of intertextuality in the $19^{\text {th }}$-century contracts from the notary office of Józef Kalasanty Szaniawski in Łukow. The repertory of the files shows that acts of respect and permission to marry were often practiced activities at that time. In the years 1810-1811 in the firm registered a total of 63 units (33 acts of respect and 30 acts of permission). Number of the notarial documents is similar because of the reciprocity and bidirectional designated activities.

In both types of contracts we find many signs of bilateral relations textual references in the form of structural and pragmatic interactions and communication. The article indicates them, describes and presents the conditions and functions of intertextual references.

Key words: acts of respect, acts of permission to marry, notarial contracts, intertextuality, $19^{\text {th }}$-century. 